\title{
A comparative study of management system of unregulated agricultural pesticides in Korea, the European Union, and the United States of America: a review
}

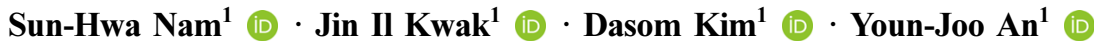

\section{비규제 농약 관리를 위한 한국, 유럽, 미국의 농약관리체계 비교분석}

남선화 ${ }^{1}$ - 곽진일 ${ }^{1}$ - 김다솜1 ${ }^{1}$ 안윤주 ${ }^{1}$

Received: 17 April 2018 / Accepted: 5 June 2018 / Published Online: 30 June 2018

(C) The Korean Society for Applied Biological Chemistry 2018

\begin{abstract}
Pesticide residue in the eggs in the market has become a significant problem in Korea. In particular, the detection of fipronil indicated that unregulated pesticide residue can be present in livestock products, including eggs. Institutionally unregulated pesticides are a risk to human health and the ecosystem. In this study, we analyzed the system of agricultural pesticide management in Korea, the European Union, and the United States of America (USA) and discussed the problems of the Korean management system and the possible improvement directions. Based on the analysis, we considered three tasks: registration of pesticides, pesticide residue levels in food, and pesticide residue levels in environmental media. The registration of pesticides was conducted by the Ministry of Agriculture, Food, and Rural Affairs in Korea; the Directorate-General for Health and Food Safety in the European Commission (EC); and the US Environmental Protection Agency (USEPA) in the USA. The work regarding pesticide residue levels in food was conducted by the Ministry of Food and Drug Safety in Korea, the Directorate-General for the Health and Food Safety in the EC, and the USEPA and Food and Drug Administration in the USA. The work regarding pesticide residue

Youn-Joo An $(\bowtie)$

E-mail: anyjoo@konkuk.ac.kr

${ }^{1}$ Department of Environmental Health and Science, Konkuk University, 120 Neungdong-ro, Gwangjin-gu, Seoul 05029, Republic of Korea

This is an Open Access article distributed under the terms of the Creative Commons Attribution Non-Commercial License (http://creativecommons. org/licenses/by-nc/3.0/) which permits unrestricted non-commercial use, distribution, and reproduction in any medium, provided the original work is properly cited.
\end{abstract}

levels in environmental media was conducted by the Ministry of Environment in Korea, the Directorate-General for Environment in the EC, and the USEPA in the USA. Therefore, Korea should review the extension of pesticide residue standards in the environmental media for strengthening the system of management of unregulated agricultural pesticides.

Keywords Agricultural pesticides - Management system . Pesticides

\section{서 론}

2017년 유럽 벨기에를 시작으로 계란 중 잔류 농약 검출 사례 가 보고되었고, 한국에서도 2017년 8월 계란 중 잔류 농약 실태를 파악한 결과, dichlorodiphynyltrichloroethane (DDT), bifenthrin, etoxazole, flufenoxuron, pyridaben, fipronil 등이 검출되었다[1]. 이 중 bifenthrin을 제외한 DDT, etoxazole, flufenoxuron, pyridaben, fipronil은 식품의 기준 및 규격[2]에서 제시하는 축산물의 농약 잔류허용기준 중 계란에 대한 기준치가 미제시된 항목이다. 특 히 fipronil은 닭 진드기 방제를 위한 살충제로 사용되었으나, 현재 강한 독성으로 인해 축산물에의 사용이 금지된 물질이다 [3]. 한국은 농약에 대해 부처(농림축산식품부, 식품의약품안전 처, 환경부)별 법령(농약관리법, 식품위생법, 물환경보전법, 수질 및 수생태계 보전에 관한 법, 토양환경보전법, 지하수의 수질보 전 등에 관한 규칙, 먹는물 수질기준 및 검사 등에 관한 규칙 등)에 따라 제도적으로 관리하고 있다[4]. 그러나 fipronil과 같 이 비규제 농약으로 인해 국민건강 위해 및 환경오염 문제가 
나타날 가능성이 있으므로, 농약 관련 사회적 문제가 발생한 후 이를 보완하기 위한 제도를 개정하였다. 이에 따라 2018년 4월 축산물의 농약 잔류허용기준 항목에서 사료로부터 비의도적으 로 이행되어 축산물에 잔류가능성이 있는 농약 15종(fipronil, etoxazole, flufenoxuron, pyridaben 등)을 신설하여 제도적으로 관리할 예정이며[4], 국내 사용 등록 또는 잔류 허용 기준 설정 된 농약 이외 물질에 대해 원칙적으로 사용을 금지하기 위해 모든 농산물을 대상으로 농약 허용 물질 목록 관리제도(Positive List System, PLS)를 2019년 1월부터 시행할 예정이다[5].

농약은 '농작물을 해치는 균, 곤충, 응애, 선충, 바이러스, 잡 초, 그 밖에 농림축산시품부령으로 정하는 동식물을 방제하는 데에 사용하는 살균제·살충제·제초제, 또는 농작물의 생리기 능을 증진하거나 억제하는 데에 사용하는 약제, 또는 그 밖에 농림축산식품부령으로 정하는 약제’로서[6], 농업 생산 분야의 주요 생산자재이다. 한국의 농약 생산량은 2005년(165,449톤) 에 비해 2017년(131,240톤) 34,209톤 감소하였으며[7,8], 현행 법령에 의해 제도적으로 농약을 관리하고 있으나, 계란 중 잔 류 농약 사태와 같이 비규제 농약에 의한 국민건강 위해 및 환 경오염 발생을 배제할 수 없다.

따라서 본 연구에서는 한국, 유럽연합, 미국의 부처 및 산하 협력기관의 담당 법령 및 업무 관련 농약관리체계 비교 분석을 통해 현 시점에서 한국의 농약관리체계의 문제점을 파악하고, 비규제 농약에 관한 개선 방향을 모색하고자 한다.

\section{한국의 농약관리체계}

한국은 농림축산식품부, 식품의약품안전처, 환경부를 주축으로 농약 관련 법령(농약관리법, 농수산물 품질관리법, 식품위생법, 물환경보전법, 토양환경보전법, 수질 및 수생태계 보전에 관한 법), 고시, 예규를 시행 중이다(Table 1)[4]. 농약의 등록 및 제 조, 수입 판매, 사용 등 전반적인 관리는 농림축산부 산하 농촌 진흥청에서 담당하고, 식품 중 농약 잔류허용기준은 식품의약품 안전처에서 담당하며, 환경(물 또는 토양) 중에 노출된 잔류 농 약 및 환경기준은 환경부에서 담당하고 있다(Fig. 1). 농림축산 식품부는 농약관리법을 중심으로, 식품산업정책실(농업생명정책 관-농기자재정책팀), 농촌진흥청(연구정책국-농자재산업과), 국립 농업과학원(농산물안전성부-화학물질안전과 및 농자재평가과)과 협력하여 농약 사용량 등 통계, 농약유통, 농약품질관리, 농약 업/품목등록 및 변경, 농약판매관리인 교육, 농약독성연구, 잔류 농약 안전성연구, 농작물 중 농약행적 및 대사평가, 수출농산물 농약 안전관리, 농약위해성평가, 농약의 환경 중 행적 평가, 농 약 이화학성생물활성평가 등을 담당하고 있다 $[9,10,11]$. 식품의 약품안전처는 식품위생법을 중심으로, 식품안전정책국(식품기준 기획관-유해물질기준과), 식품위해평가부(잔류물질과)와 협력하 여 잔류농약 기준 설정, 식품 중 잔류농약 위해성 평가, 신규 시험법 개발, 노출실태조사, 기준설정, 인허가 심사지원을 담당 하고 있다[12,13]. 환경부는 물환경보전법, 수질 및 수생태계 보 전에 관한 법을 중심으로 물환결정책국(물환경정책과)과 협력하 여 토양 및 수계 내 농약 잔류량 및 하천, 호소 중 농약 관리 를 담당하고 있으며, 토양환경보전법, 지하수의 수질보전 등에 관한 규칙을 중심으로 물환경정책국(상하수도정책관-토양지하수 과)과 협력하여 골프장의 농약사용량 조사, 토양오염기준 내 농 약 설정 및 위해성평가, 지하수오염기준 내 농약 설정 및 위해
성평가를 담당하고 있다[14]. 또한 먹는물 수질기준 및 검사 등 에 관한 규칙을 중심으로 상하수도정책관(수도정책과)과 협력하 여 먹는물기준 내 농약 설정 및 위해성평가를 담당하고 있으며, 국립환경과학원(환경기반연구부-상하수도연구과 및 토양지하수 연구과)과 협력하여 먹는물기준, 토양오염기준, 지하수오염기준 내 농약 설정 및 위해성평가, 골프장 농약환경영향조사를 담당 하고 있다[14,15]. 특히 환경매체 중 잔류농약기준은 법률 제 14490 호 수질 및 수생태계 보전에 관한 법률의 수질오염물질, 특정수질유해물질, 수질오염물질의 배출허용기준, 환경부령 제 696호 지하수의 수질보전 등에 관한 규칙의 특정유해물질, 법 률 제 15102 호 토양환경보전법의 토양오염물질, 토양오염우려기 준, 토양오염대책기준으로서 유기인 화합물을 제시하고 있다. 그 리고 환경부령 제684호 먹는물 수질기준 및 검사 등에 관한 규 칙에서만 건강상 유해영향 유기물질로서 diazinon, parathion, fenitrothion, carbaryl 4개 항목에 대해 개별 기준을 제시하고 있다 $[16,17,18,19]$. 한편 국내 농약관련 현행제도는 규제물질에 대해 기준을 적용하고 있어 비규제 물질에 대한 관리가 소홀함 에 따라, 이러한 제도적 사각지대를 해결하기 위해 관련 제도 를 개정할 예정이다. 특히 식품 중 잔류농약 관련하여, 일부 견 과종실류 및 열대과일류 대상으로 잔류허용기준이 설정된 농산 물은 현행 기준을 적용하고, 잔류허용기준이 미설정된 농산물은 국제기준 코덱스 또는 유사 농산물 기준을 적용하였다. 이에 따 라 미등록 농약이 사용된 농산물에 의한 식품 안전성이 위협되 므로, 농약 허용물질목록 관리제도를 통해 과일, 채소 등 전 농 산물을 대상으로 $0.01 \mathrm{ppm}$ 잔류허용기준이 2019년 1월부터 시 행될 예정이다[5]. 또한 축산물의 농약 잔류허용기준 항목은 사 료로부터 비의도적으로 이행되어 축산물에 잔류가능성이 있는 농약 15종(clothianidin, fipronil, imidacloprid, spinosad, ivermectin, amitraz, abamectin, cartap, chlorfenapyr, etoxazole, flufenoxuron, pyridaben, spiromesifen, thiocyclam, tetraconazol)을 신설할 예 정이다[20].

\section{유럽연합의 농약관리체계}

유럽연합의 pesticide는 유해생물 또는 질병을 방지, 사멸, 제어 하거나 생산, 저장, 유통 과정 중 작물이나 작물제품을 보호하 기 위한 것으로, 작물보호제(Plant protection products)와 살생물 제(Biocidal products)를 포함한다[21,22]. 유럽연합의 작물보호 제는 주로 농업 분야나 산림, 원예, 생활편의지역, 집 정원 등 에서 작물을 보호하기 위해 사용되는 pesticide를 의미하므로, 국내 농약과 유사한 개념이다. 유럽연합은 유럽집행위원회를 주 축으로 농약 관련 Regulation, Directive, Council directive를 시행 중이다(Table 2; Fig. 2). 보건식품안전국은 유럽식품안전 청과 협력하여 식품 및 사료 중 잔류농도 및 시중 작물보호제 승인 관련 정책 입안 및 시행을 담당하고 있으며, 유럽식품안 전청은 식품 위해성 관련 과학적 자문을 담당하고 있다[23-41]. 특히 식품 중 농약의 최대잔류농도(Maximum residue levels, MRLs)는 과거 사용됐거나 현재 사용되는 1,100 여개 pesticides 를 관리하며, 비-특이적 pesticides는 기본값 $0.01 \mathrm{mg} / \mathrm{kg}$ 을 설정 하여 규정하고 있다[27]. 환경국은 유럽환경청과 협력하여 작물 보호제의 지속가능한 사용, 종합물관리, 지하수질, 지표수질, 식 용수질 관련 정책 입안 및 시행을 담당하고 있으며, 유럽환경 청은 환경 정책 입안자 및 대중에 환경 정보 제공을 담당하고 
Table 1 Law lists for agricultural pesticide in Korea [4]

\begin{tabular}{ll}
\hline \hline & \multicolumn{1}{c}{ Law title } \\
\hline Ministry of Agriculture, Food and Rural Affairs & Year \\
Pesticide control act & 2017 \\
Enforcement decree of the pesticide control act & 2017 \\
Enforcement regulation of the pesticide control act & 2017 \\
Criteria and standards for feed & 2017 \\
Institutional test guidelines to register pesticide for plant quarantine & 2016 \\
Rural Development Administration & 2016 \\
Regulation for designation of committed institution and treatment of committed work for training seller of pesticides & 2016 \\
Designation and registration standards of agricultural machinery and equipment & 2017 \\
Pesticides for Record and preservation of information of buyer & 2017 \\
Handling restriction standards for pesticides and active substances & 2017 \\
Designation and management standards for test research institution of pesticides & 2017 \\
Safe use standards of pesticides & 2017 \\
Registration standard for pesticides and active substances & 2017 \\
Labeling standards for pesticides, active substances, and agricultural machinery and equipment & 2017 \\
Inspection method of pesticides and treatment tact of adulterated pesticides & 2017 \\
Acceptance standards of exportation and importation for pesticides & 2017 \\
Revocation of registration and restriction on disposal by authority & 2017 \\
Vendable pesticide by communication or cold call & 2016 \\
Business process guide related to examination of registration application document for pesticides, active substances, and agricultural machinery & 2016 \\
and equipment &
\end{tabular}

Ministry of Agriculture, Food and Rural Affairs, Ministry of Food and Drug Safety, Ministry of Oceans and Fisheries

Agricultural and marine products quality control act 2017

Food sanitation act $\quad 2017$

Enforcement decree of the food sanitation act 2017

Enforcement regulation of the food sanitation act 2017

Rule related to functional raw material of health functional food and qualification of criteriastandards 2016

Criteria and standards for food 2016

Tact for residue investigation of harmful substances in agricultural products 2017

Regulation related to inspection for imported food 2017

Ministry of Environment

Water quality conservation act $\quad 2017$

Regulation related to inspection method of pesticide residue and investigation of pesticide usage in golf course 2016

Soil environment conservation act 2017

Enforcement decree of the soil environment conservation act 2017

Enforcement regulation of the soil environment conservation act 2017

Water quality and aquatic ecosystem conservation act 2016

Enforcement decree of the water quality and aquatic ecosystem conservation act 2017

Enforcement regulation of the water quality and aquatic ecosystem conservation act 2017

Regulation related to water quality standards and inspection for drinking water 2016

Regulation related to water quality conservation for groundwater 2017

Application and operation guideline on test method of exposure assessment for pesticides containing child goods 2013

있다[42-49]. 특히 내륙성 지표수, 해파(transitional waters), 연 안수(coastal water), 지하수 보호를 위한 물관리 지침의 부록 $\mathrm{III}$ 을 통해 유기인계 화합물, 살생물제, 작물보호제를 주요 오염 물질의 지표로 제시하고 있으며[44], 지하수 보호를 위한 지침 의 부록 I을 통해 pesticides 중 활성물질에 대한 지하수질 기준 을 $0.1 \mu \mathrm{g} / \mathrm{L}$ (개별물질) 및 $0.5 \mu \mathrm{g} / \mathrm{L}$ (총합)로 제시하고 있다 (European Union, 2006b). 또한 지표수질 보호를 위한 지침의 부록 I을 통해 alachlor, atrazine, chlorfenvinphos, chlorpyrifos, cyclodiene pesticides (aldrin, dieldrin, endrin, isodrin), DDT, diuron, endosulfan, fluoranthene, isoproturon, simazine, trifluralin 등의 pesticides에 대한 연평균농도 및 최대허용농도를 제시하고 있으며[47], 음용, 조리 등의 식용 목적으로 사용되는 수질에 관 한 지침의 부록 I을 통해 pesticides의 수치를 $0.1 \mu \mathrm{g} / \mathrm{L}$ (개별물 질; 단, aldrin, dieldrin, heptachloro, heptachlor epoxide만 $0.03 \mu \mathrm{g} / \mathrm{L}$ ) 및 $0.5 \mu \mathrm{g} / \mathrm{L}$ (총합)로 제시하고 있다[43]. 통계청은 시중 작물보호제 통계 관련 정책 입안 및 시행을 담당하고 있다. 


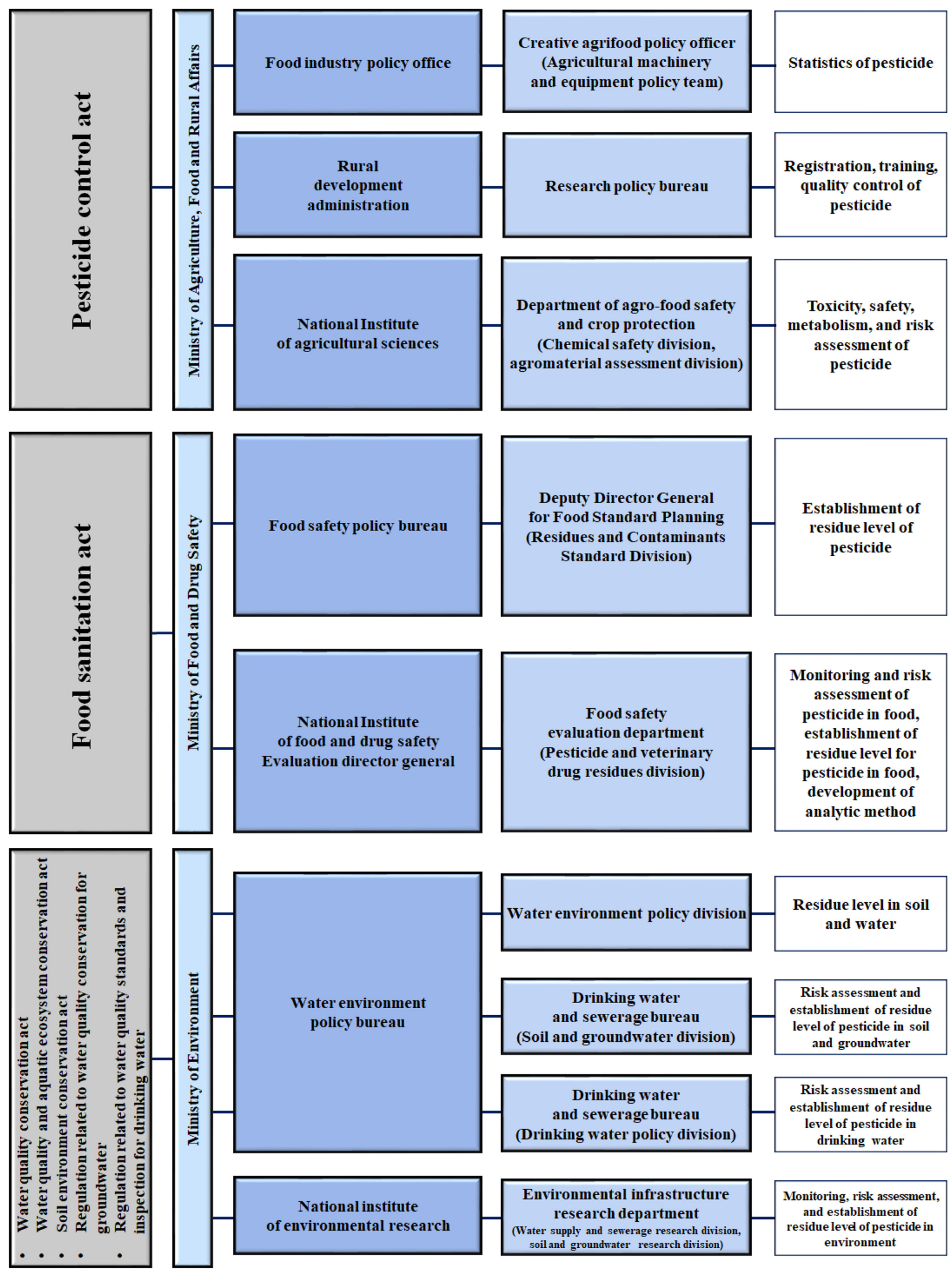

Fig. 1 Management system for agricultural pesticides in Korea 
Table 2 Law lists for agricultural pesticide in European Commission (EC)

LC Directorate-General for health and consumers $\quad$ Year

\section{EC Directorate-General for health and consumers}

Regulation (EC) No 396/2005 of the European Parliament and of the Council of 23 February 2005 on maximum residue levels of pesticides in or on food and feed of plant and animal origin and amending Council Directive 91/414/EEC

Regulation (EC) No 1107/2009 of the European Parliament and of the Council of 21 October 2009 concerning the placing of plant protection products on the market and repealing Council Directives 79/117/EEC and 91/414/EEC

Commission Regulation (EU) No 540/2011 of 25 May 2011 implementing Regulation (EC) No 1107/2009 of the European Parliament and of the Council as regards the list of approved active substances

Commission Regulation (EU) No 546/2011 of 10 June 2011 implementing Regulation (EC) No 1107/2009 of the European Parliament and of the Council as regards uniform principles for evaluation and authorisation of plant protection products

Commission Regulation (EU) No 547/2011 of 8 June 2011 implementing Regulation (EC) No 1107/2009 of the European Parliament and of the Council as regards labelling requirements for plant protection products

Commission Regulation (EU) No 283/2013 of 1 March 2013 setting out the data requirements for active substances, in accordance with Regulation (EC) No 1107/2009 of the European Parliament and of the Council concerning the placing of plant protection products on the market of 1 March 2013 setting out the data requirements for plant protection products, in accordance with Regulation (EC) No 1107/2009 of the European Parliament and of the Council concerning the placing of plant protection products on the market

Commission Regulation (EU) No 284/2013 of 1 March 2013 setting out the data requirements for plant protection products, in accordance with Regulation (EC) No 1107/2009 of the European Parliament and of the Council concerning the placing of plant protection products on the market Commission Regulation (EC) No 33/2008 of 17 January 2008 laying down detailed rules for the application of Council Directive 91/414/EEC as regards a regular and an accelerated procedure for the assessment of active substances which were part of the programme of work referred to in Article 8(2) of that Directive but have not been included into its Annex I

Commission Regulation (EC) No 1095/2007 of 20 September 2007 amending Regulation (EC) No 1490/2002 laying down further detailed rules for the implementation of the third stage of the programme of work referred to in Article 8(2) of Council Directive 91/414/EEC and Regulation (EC) No 2229/2004 laying down further detailed rules for the implementation of the fourth stage of the programme of work referred to in Article 8(2) of Council Directive 91/414/EEC

Commission Regulation (EEC) No 3600/92 of 11 December 1992 laying down the detailed rules for the implementation of the first stage of the programme of work referred to in Article 8 (2) of Council Directive 91/414/EEC concerning the placing of plant protection products on the market Commission Regulation (EC) No 451/2000 of 28 February 2000 laying down the detailed rules for the implementation of the second and third stages of the work programme referred to in Article 8(2) of Council Directive 91/414/EEC

Commission Regulation (EC) No 1490/2002 of 14 August 2002 laying down further detailed rules for the implementation of the third stage of the programme of work referred to in Article 8(2) of Council Directive 91/414/EEC and amending Regulation (EC) No 451/2000

Commission Regulation (EC) No 2229/2004 of 3 December 2004 laying down further detailed rules for the implementation of the fourth stage of the programme of work referred to in Article 8(2) of Council Directive 91/414/EEC

Commission Regulation (EC) No 188/2011 of 25 February 2011 laying down detailed rules for the implementation of Council Directive 91/414/EEC as regards the procedure for the assessment of active substances which were not on the market 2 years after the date of notification of that Directive

Commission Regulation (EC) No 737/2007 - of 27 June 2007 on laying down the procedure for the renewal of the inclusion of a first group of active substances in Annex I to Council Directive 91/414/EEC and establishing the list of those substances

Commission Regulation (EC) No 1141/2010 - of 7 December 2010 laying down the procedure for the renewal of the inclusion of a second group of active substances in Annex I to Council Directive 91/414/EEC and establishing the list of those substances

Commission Regulation (EC) No 844/2012 - of 18 September 2012 setting out the provisions necessary for the implementation of the renewal procedure for active substances, as provided for in Regulation (EC) No 1107/2009 of the European Parliament and of the Council concerning the placing of plant protection products on the market

Commission Regulation (EC) No 686/2012 - of 26 July 2012 allocating to Member States, for the purposes of the renewal procedure, the evaluation of the active substances whose approval expires by 31 December 2018 at the latest

Commission Regulation (EC) No 2016/183 - of 11 February 2016 amending Implementing Regulation (EU) No 686/2012 allocating to Member States, for the purposes of the renewal procedure, the evaluation of the active substances whose approval expires by 31 December 2018 at the latest

\section{EC Statistical office}

Regulation (EC) No 1185/2009 of the European Parliament and of the Council of 25 November 2009 concerning statistics on pesticides

\section{미국의 농약관리체계}

미국의 pesticide는 연방 살충제·살균제·살서제법(Federal insecticide, fungicide, and rodenticide act)에 따라 유해생물의 방지, 파괴, 격퇴, 경감 물질 또는 혼합물, 식물생장조절물질, 고 엽제, 건조제 용도로 사용되는 물질 또는 혼합물, 질소안정제를 포함한다. 미국은 환경부, 식품의약처, 농무부를 주축으로 농약 관련 law 및 act를 시행 중이다(Table 3; Fig. 3). 환경부는 Safe Drinking Water Act (SDWA), Clean Water Act (CWA),
Comprehensive Environmental Response, Compensation, and Liability Act (CERCLA), Pesticide Registration Improvement Extension Act (PRIA3), FIFRA, Federal Food, Drug, and Cosmetic Act (FFDCA)를 중심으로 지하수먹는물 사무국, 폐수 관리국, 수퍼펀드 정화 및 기술혁신국, 농약프로그램 사무국과 협력하여 먹는물, 지표수 준거치, 토양 screening level 설정, 배 출수 관리 우선순위 물질 선정, 농약 등록비, 생산, 사용, 등록, 식품 내 잔류 최대농도 설정을 담당하고 있다[50-55]. 특히 인 
Table 2 Continued

Law title Year

\section{EC Directorate-General for environment}

Directive 2009/128/EC of the European Parliament and of the Council of 21 October 2009 establishing a framework for Community action to achieve the sustainable use of pesticides

Regulation (EU) No 528/2012 of the European Parliament and of the Council of 22 May 2012 concerning the making available on the market and use of biocidal products

Directive 2000/60/EC of the European Parliament and of the Council of 23 October 2000 establishing a framework for Community action in the field of water policy

Directive 2006/118/EC of the European Parliament and of the Council of 12 December 2006 on the protection of groundwater against pollution and deterioration

Directive 2008/105/EC of the European Parliament and of the Council of 16 December 2008 on environmental quality standards in the field of water policy, amending and subsequently repealing Council Directives 82/176/EEC, 83/513/EEC, 84/156/EEC, 84/491/EEC, 86/280/EEC and 2008 amending Directive 2000/60/EC of the European Parliament and of the Council

Council directive 98/83/EC of 3 November 1998 on the quality of water intended for human consumption

Decision No 1386/2013/EU of the European Parliament and of the Council of 20 November 2013 on a General Union Environment Action

Programme to 2020 'Living well, within the limits of our planet'

Council directive 91/271/EEC of 21 May 1991 concerning urban waste-water treatment

Directive 2008/50/EC of the European Parliament and of the Council of 21 May 2008 on ambient air quality and cleaner air for Europe
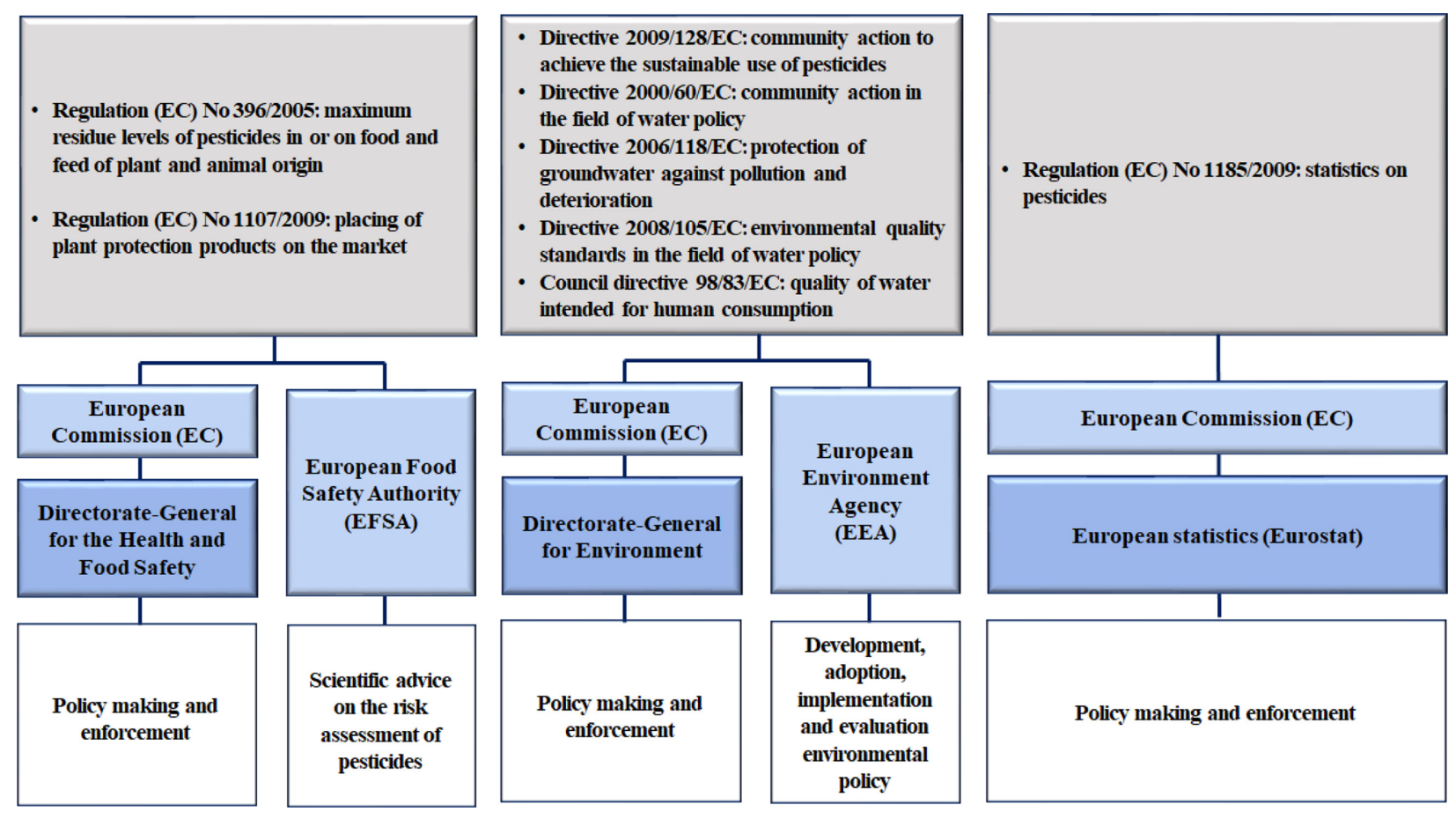

Fig. 2 Management system for agricultural pesticides in EC

체건강 보호를 위한 수질준거치, 담수 및 해수 생태계 보호를 위한 수질준거치(Aldrin 등), 배출수 관련 우선순위물질 목록 (aldrin, dieldrin, chlordane, 4,4-DDT, 4,4-DDE, 4,4-DDD, alpha-endosulfan, beta-endosulfan, endosulfan sulfate, endrin, endrin aldehyde, heptachlor, heptachlor epoxide, alpha-BHC, beta-BHC, gamma-BHC, delta-BHC, toxaphene), 토양 screening level, 먹는물 기준 중 pesticde가 포함되어 있다[56-59]. 식품의 약처는 FFDCA를 중심으로 식품안전 및 응용 영양센터와 협력 하여 식품 및 사료 중 농약 감시, 농약 프로그램 운영, 연간보 고서, 잔류 모니터링 데이터베이스, 농약 화학물질 용어집, 농
약 분석 매뉴얼, 총 식품 연구자료를 담당하고 있으며[60], 농 무부는 FFDCA를 중심으로 농업마켓서비스와 협력하여 육류 및 가금류 농약 감시, 원자재 잔류 농약 모니터링을 담당하고 있 다[61]. 특히 코덱스 $\mathrm{MRLs}$ 에 따라 식품 중 잔류농약을 관리하 고 있다[62].

\section{결 론}

농약 관련 부처 및 산하 협력기관의 담당 법령 및 업무를 한국, 
Table 3 Law lists for agricultural pesticide in United States of America (USA)

\section{Law title}

United States Environmental Protection Agency (US EPA), United States Food and Drug Administration (US FDA), and United States Department of Agriculture (US DA)

Federal Food, Drug and Cosmetic Act (FFDCA)

United States Environmental Protection Agency

Federal Insecticide, Fungicide, and Rodenticide Act (FIFRA) 7 U.S.C. §136 et seq. (1996) 1996

Pesticide Registration Improvement Extension Act (PRIA3)

Clean Water Act (CWA)

Clean Water Act. Code of Federal Regulations at 40 CFR Part 423, Appendix A

Comprehensive Environmental Response, Compensation and Liability Act (CERCLA)

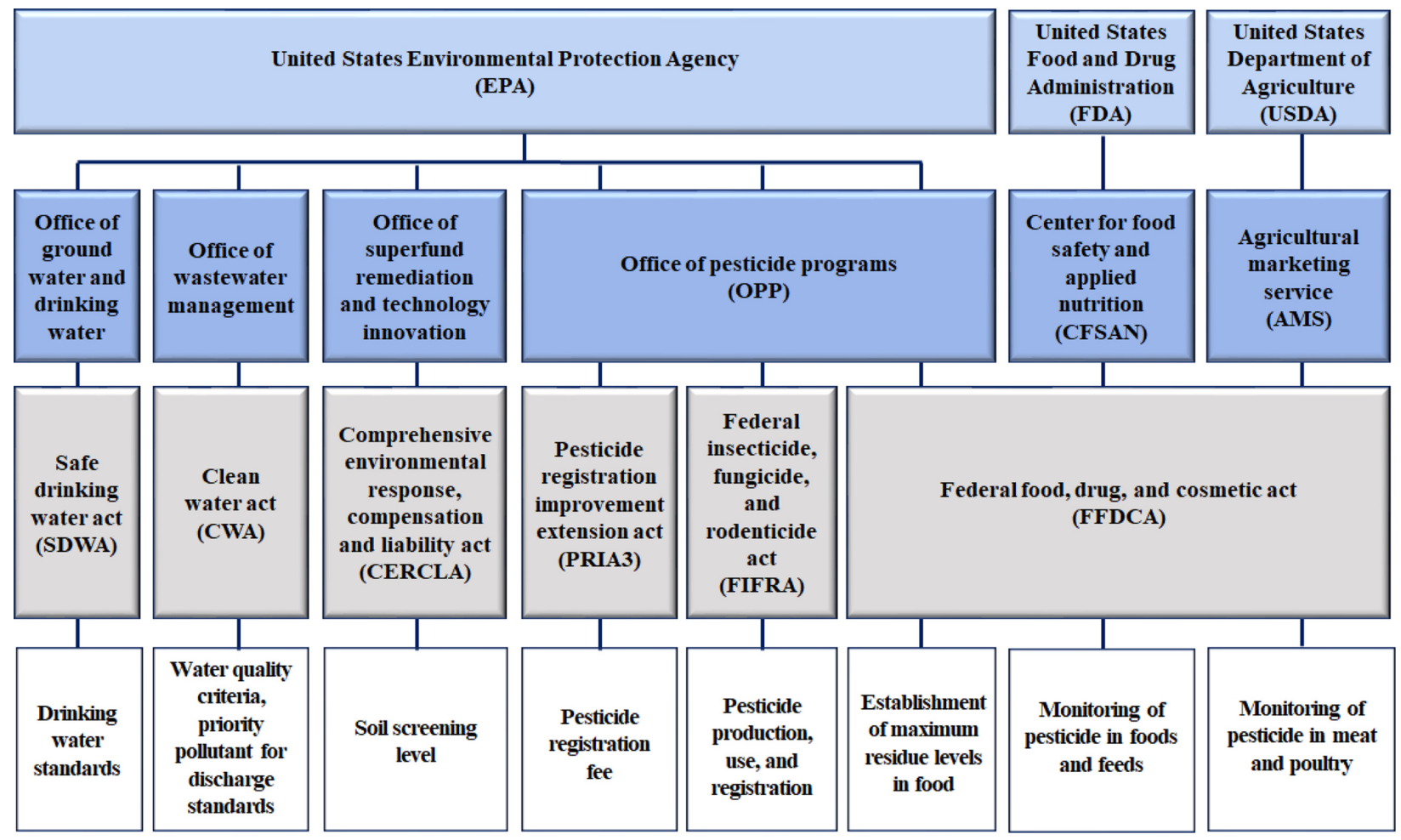

Fig. 3 Management system for agricultural pesticides in USA

유럽연합, 미국을 중심으로 비교한 결과, 농약과 관련하여 농약 등록, 식품 중 잔류농약, 환경매체 중 잔류농약에 대한 3가지 부분으로 분류되는 것으로 나타났다(Table 4). 먼저 농약 등록 부분은 농약을 시중 유통시키기 위해 농약의 기본정보(이화학 성, 독성, 위해성 등)를 바탕으로 검토 및 승인 절차를 거쳐 등 록시키는 것으로, 한국은 농림축산식품부 중심으로 운영되나 유 럽연합은 유럽집행위원회의 보건식품안전국, 미국은 미국환경부 중심으로 운영되는 것으로 나타났다. 또한 식품 중 잔류농약 부 분은 식품 안전성을 증대시키기 위해 식품 중 잔류농약 기준 설정 및 모니터링을 수행하는 것으로, 한국은 식품의약품안전처 중심으로 운영되나 유럽연합은 유럽집행위원회의 보건식품안전 국, 미국은 미국환경부(식품 중 잔류농약농도 설정)와 식품의약
처(식품 및 사료 중 농약 모니터링)가 분업하는 것으로 나타났 다. 그리고 환경매체 중 잔류농약 부분은 국민건강 및 환경상 의 위해를 예방하기 위해 환경매체 중 잔류농약 기준 설정 및 모니터링을 수행하는 것으로, 한국, 유럽연합, 미국 모두 환경 부, 유럽집행위원회의 환경국, 미국환경부 중심으로 운영되는 것 으로 나타났다. 제도적 농약 관리를 위해, 미국은 환경부가 주 도적으로 농약 등록, 식품 및 환경매체 중 잔류농약기준 설정 에 관여하며, 식품의약처가 식품 중 농약 모니터링 업무를 보 조한다. 반면 유럽연합은 한국과 유사하게 농림축산식품부와 식 품의약품안전처의 역할을 통합한 유럽집행위원회의 보건식품안 전국에서 농약 등록, 식품 중 잔류농약기준 설정에 관여하는 것 으로 나타났다. 한국의 비규제 농약에 관한 현행 농약관리체계 
Table 4 Comparison of management system for agricultural pesticide in Korea, EC, and USA

\begin{tabular}{|c|c|c|c|}
\hline Government body & Role & Amendment & Comparison with EC and USA \\
\hline $\begin{array}{l}\text { Ministry of Agriculture, Food and } \\
\text { Rural Affairs } \\
\text { (Rural Development Administration, } \\
\text { National Institute of Agricultural } \\
\text { Sciences) }\end{array}$ & $\begin{array}{l}\text { - Registration and distribution } \\
\text { - Physico-chemical and toxicological } \\
\text { study } \\
\text { - Safe use standard }\end{array}$ & . & $\begin{array}{l}\text { - Concerned in EC Directorate- } \\
\text { General for health and consumers } \\
\text { - Concerned in US EPA }\end{array}$ \\
\hline $\begin{array}{l}\text { Ministry of Food and Drug Safety } \\
\text { (National Institute of Food and Drug } \\
\text { Safety Evaluation) }\end{array}$ & $\begin{array}{l}\text { - Establishment, monitoring, and risk } \\
\text { assessment of residue level in food } \\
\text { - Development of analytical method } \\
\text { for residue level in food }\end{array}$ & $\begin{array}{l}\text { - Establishment of } 0.01 \text { ppm for } \\
\text { residue level in all agricultural } \\
\text { products (enforcement date: January } \\
2019 \text { ) } \\
\text { - Addition of } 15 \text { agricultural } \\
\text { pesticides in livestock products }\end{array}$ & $\begin{array}{l}\text { - Concerned in EC Directorate- } \\
\text { General for health and consumers } \\
\text { - Concerned in US EPA and US FDA }\end{array}$ \\
\hline $\begin{array}{l}\text { Ministry of Environment } \\
\text { (National Institute of Environmental } \\
\text { Research) }\end{array}$ & $\begin{array}{l}\text { - Establishment, monitoring, and risk } \\
\text { assessment of residue level in } \\
\text { environment (surface water, } \\
\text { drinking water, groundwater, and } \\
\text { soil) }\end{array}$ & - & $\begin{array}{l}\text { - Concerned in EC Directorate- } \\
\text { General for environment } \\
\text { - Concerned in US EPA }\end{array}$ \\
\hline
\end{tabular}

를 강화하기 위해, 환경매체 중 잔류농약기준 관련 제도 확대 를 검토할 필요가 있다. 유럽연합은 지하수, 지표수, 식용수를 대상으로, 미국은 지표수, 배출수, 먹는물, 토양을 대상으로 농 약기준을 제시하고 있으며, 농약 총량뿐만 아니라 개별물질에 대해서도 제시한 바 있다. 특히 한국은 환경매체 중 잔류농약 기준을 지표수, 배출수, 지하수, 토양에 대해 유기인 화합물로 제시하고 있으며, 먹는물에 한해 diazinon, parathion, fenitrothion, carbaryl 4개 항목에 대한 개별 기준을 제시하고 있다. 그러나 2016년 농업용수 모니터링 결과에서 국내 금지 농약인 유기염 소계 endosulfan의 검출빈도가 높은 것으로 나타났다[63]. 또한 사람이 식용으로 하지 않는 잔디에 사용되는 약제나 미생물제, 무기농약 또는 수확물에 잔류가 되지 않는 농약 등은 농약안전 사용기준 설정 제외대상이므로 환경매체 중 잔류농약기준을 확 대하는 것이 필요하다. 따라서 환경매체 중 잔류농약기준은 유 기인 중심에서 유기염소계, 카바메이트계, 동계, 피레스로이드계, 페녹시계 등 농약의 주성분별 항목 확대를 검토할 필요가 있으 며, 각 계열별 농약 중 개별 항목(예. 유기인계(parathion, malathion, diazinon 등), 유기염소계(aldrin, clodine, endrin 등)) 으로의 확대를 검토할 필요가 있다.

\section{초 록}

국내외적으로 계란 중 잔류 농약 검출 사례가 보고되었고, 한 국에서도 축산물의 농약 잔류허용기준 중 계란에 대한 기준치 가 미제시된 항목인 fipronil 등이 검출되었다. 비규제 농약으로 인해 국민건강 위해 및 환경오염 문제가 나타날 가능성이 있으 므로, 한국, 유럽연합, 미국의 부처 및 산하 협력기관의 담당 법 령 및 업무 관련 농약관리체계 비교 분석을 통해 현 시점에서 한국의 농약관리체계의 문제점을 파악하고, 비규제 농약에 관한 개선 방향을 모색하였다. 한국, 유럽연합, 미국의 농약관리체계 비교한 결과, 농약 등록, 식품 중 잔류농약, 환경매체 중 잔류 농약으로 크게 나누어 관리하는 것으로 나타났다. 농약을 시중 유통시키기 위해 농약의 기본정보(이화학성, 독성, 위해성 등)를 바탕으로 검토 및 승인 절차를 거치는 농약 등록 부분은 한국
의 농림축산식품부, 유럽집행위원회의 보건식품안전국, 미국환 경부가 관여하는 것으로 나타났다. 식품 안전성을 증대시키기 위해 식품 중 잔류농약 기준 설정 및 모니터링을 수행하는 부 분은 한국의 식품의약품안전처, 유럽집행위원회의 보건식품안전 국이 전담하나, 미국은 미국환경부(식품 중 잔류농약농도 설정) 와 식품의약처(식품 및 사료 중 농약 모니터링)가 분업하는 것 으로 나타났다. 국민건강 및 환경상의 위해를 예방하기 위해 환 경매체 중 잔류농약 기준 설정 및 모니터링을 수행하는 부분은 한국, 유럽연합, 미국 모두 환경부, 유럽집행위원회의 환경국, 미국환경부 중심으로 운영되는 것으로 나타났다. 한국은 부처간 협의를 통해 농약관리를 제도적으로 수행하고 있으나, 비규제 농약에 대한 관리를 강화하기 위해 환경매체 중 잔류농약기준 항목의 계열 확대 및 개별항목 신설을 검토할 필요가 있다.

Keywords 관리체계 · 농약

감사의 글 본 연구는 환경부 화학물질 유 위해성 정보관리 특성화 대학원 의 지원으로 수행되었습니다.

\section{References}

1. Ministry of Food and Drug Safety (2017) Press release. Result on collection and inspection for extended application of inspection substances for eggs distributed on the market, Osong

2. Ministry of Food and Drug Safety (2018) Notification No. 2018-18. Amendment on criteria and standard for food, Osong

3. Kang SM, Lee CH, Park, OJ, Leem JH, Yoon HJ, Kweon OK (2002) Efficacy of fipronil-applied canine hair against house dust mites. J Vet Clin 19: 215-218

4. Ministry of Government Legislation (2018) http://www.moleg.go.kr. Accessed 16 April 2018

5. Ministry of Food and Drug Safety (2015) Notification at 2015-78. Amendment on criteria and standard for food, Osong

6. Ministry of Government Legislation (2018) Act No. 14532. Pesticide control act

7. Korea Crop Protection Association (2006) Current state of production and shipment for pesticides, Seoul

8. Korea Crop Protection Association (2018) Current state of production 
and shipment for pesticides, Seoul

9. Ministry of agriculture, Food and Rural Affairs (2018) Organization. http://www.mafra.go.kr/mafra/437/subview.do. Accessed 16 April 2018

10. National Institute of agricultural sciences (2018) http://www.naas.go.kr/ 04 intro/Intro_Greeting.do?tg $=1 \&$ mmode $=3 \&$ menu_code $=4$. Accessed 16 April 2018

11. Rural Development Administration (2018) Organization. http:// www.rda.go.kr/board/board.do?mode=html\&prgId=ogi_orgfnbrQuery Accessed 16 April 2018

12. Ministry of Food and Drug Safety (2018) Organization. http:// www.mfds.go.kr/index.do?mid=750. Accessed 16 April 2018

13. National Institute of food and drug safety Evaluation director general (2018) Organization. http://www.mfds.go.kr/index.do?mid=938. Accessed 16 April 2018

14. Ministry of Environment (2018) Organization. http://www.me.go.kr/ home/web/index.do?menuId=314. Accessed 16 April 2018

15. National institute of environmental research (2018) Organization. http:// www.nier.go.kr/NIER/kor/in/nier-in-3601.do?menuNo=11004. Accessed 16 April 2018

16. Ministry of Government Legislation (2018) Act No. 14490. Water quality and aquatic ecosystem conservation act, Sejong

17. Ministry of Government Legislation (2018) Act No. 15102. Soil environment conservation act, Sejong

18. Ministry of Government Legislation (2018) Regulation No. 684. Regulation related to water quality standards and inspection for drinking water, Sejong

19. Ministry of Government Legislation (2018) Regulation No. 696. Regulation related to water quality conservation for groundwater, Sejong

20. Ministry of Food and Drug Safety (2018) Announcement No. 2018-139. Administrated notice on amendment on criteria and standard for food, Osong

21. European Union (2009) Official journal of the European Union. Directive 2009/128/EC of the European Parliament and of the Council of 21 October 2009 establishing a framework for Community action to achieve the sustainable use of pesticides, Strasbourg

22. European Union (2009) Official journal of the European Union Regulation (EC) No 1185/2009 of the European Parliament and of the Council of 25 November 2009 concerning statistics on pesticides, Strasbourg

23. European Union (1992) Official journal of the European Union. Commission Regulation (EEC) No 3600/92 of 11 December 1992 laying down the detailed rules for the implementation of the first stage of the programme of work referred to in Article 8 (2) of Council Directive 91/ 414 /EEC concerning the placing of plant protection products on the market, Brussels

24. European Union (2000) Official journal of the European Union. Commission Regulation (EC) No 451/2000 of 28 February 2000 laying down the detailed rules for the implementation of the second and third stages of the work programme referred to in Article 8(2) of Council Directive 91/414/EEC, Brussels

25. European Union (2002) Official journal of the European Union. Commission Regulation (EC) No 1490/2002 of 14 August 2002 laying down further detailed rules for the implementation of the third stage of the programme of work referred to in Article 8(2) of Council Directive 91/414/EEC and amending Regulation (EC) No 451/2000, Brussels

26. European Union (2004) Official journal of the European Union. Commission Regulation (EC) No 2229/2004 of 3 December 2004 laying down further detailed rules for the implementation of the fourth stage of the programme of work referred to in Article 8(2) of Council Directive 91/414/EEC, Brussels

27. European Union (2005) Official journal of the European Union Regulation (EC) No 396/2005 of the European Parliament and of the Council of 23 February 2005 on maximum residue levels of pesticides in or on food and feed of plant and animal origin and amending Council Directive 91/414/EEC, Strasbourg
28. European Union (2007) Official journal of the European Union. Commission Regulation (EC) No 737/2007 - of 27 June 2007 on laying down the procedure for the renewal of the inclusion of a first group of active substances in Annex I to Council Directive 91/414/EEC and establishing the list of those substances, Brussels

29. European Union (2007) Official journal of the European Union. Commission Regulation (EC) No 1095/2007 of 20 September 2007 amending Regulation (EC) No 1490/2002 laying down further detailed rules for the implementation of the third stage of the programme of work referred to in Article 8(2) of Council Directive 91/414/EEC and Regulation (EC) No 2229/2004 laying down further detailed rules for the implementation of the fourth stage of the programme of work referred to in Article 8(2) of Council Directive 91/414/EEC, Brussels

30. European Union (2008) Official journal of the European Union. Commission Regulation (EC) No 33/2008 of 17 January 2008 laying down detailed rules for the application of Council Directive 91/414/EEC as regards a regular and an accelerated procedure for the assessment of active substances which were part of the programme of work referred to in Article 8(2) of that Directive but have not been included into its Annex I, Brussels

31. European Union (2009) Official journal of the European Union. Regulation (EC) No 1107/2009 of the European Parliament and of the Council of 21 October 2009 concerning the placing of plant protection products on the market and repealing Council Directives 79/117/EEC and 91/414/EEC, Strasbourg

32. European Union (2010) Official journal of the European Union. Commission Regulation (EC) No 1141/2010-of 7 December 2010 laying down the procedure for the renewal of the inclusion of a second group of active substances in Annex I to Council Directive 91/414/EEC and establishing the list of those substances, Brussels

33. European Union (2011) Official journal of the European Union. Commission Regulation (EC) No 188/2011 of 25 February 2011 laying down detailed rules for the implementation of Council Directive 91/414/ EEC as regards the procedure for the assessment of active substances which were not on the market 2 years after the date of notification of that Directive, Brussels

34. European Union (2011) Official journal of the European Union. Commission Regulation (EU) No 540/2011 of 25 May 2011 implementing Regulation (EC) No 1107/2009 of the European Parliament and of the Council as regards the list of approved active substances, Brussels

35. European Union (2011) Official journal of the European Union. Commission Regulation (EU) No 546/2011 of 10 June 2011 implementing Regulation (EC) No 1107/2009 of the European Parliament and of the Council as regards uniform principles for evaluation and authorisation of plant protection products, Brussels

36. European Union (2011) Official journal of the European Union. Commission Regulation (EU) No 547/2011 of 8 June 2011 implementing Regulation (EC) No $1107 / 2009$ of the European Parliament and of the Council as regards labelling requirements for plant protection products, Brussels

37. European Union (2012) Official journal of the European Union. Commission Regulation (EC) No 686/2012-of 26 July 2012 allocating to Member States, for the purposes of the renewal procedure, the evaluation of the active substances whose approval expires by 31 December 2018 at the latest, Brussels

38. European Union (2012) Official journal of the European Union. Commission Regulation (EC) No 844/2012-of 18 September 2012 setting out the provisions necessary for the implementation of the renewal procedure for active substances, as provided for in Regulation (EC) No 1107/2009 of the European Parliament and of the Council concerning the placing of plant protection products on the market, Brussels

39. European Union (2013) Official journal of the European Union. Commission Regulation (EU) No 283/2013 of 1 March 2013 setting out 
the data requirements for active substances, in accordance with Regulation (EC) No 1107/2009 of the European Parliament and of the Council concerning the placing of plant protection products on the market of 1 March 2013 setting out the data requirements for plant protection products, in accordance with Regulation (EC) No 1107/2009 of the European Parliament and of the Council concerning the placing of plant protection products on the market, Brussels

40. European Union (2013) Official journal of the European Union. Commission Regulation (EU) No 284/2013 of 1 March 2013 setting out the data requirements for plant protection products, in accordance with Regulation (EC) No 1107/2009 of the European Parliament and of the Council concerning the placing of plant protection products on the market, Brussels

41. European Union (2016) Official journal of the European Union. Commission Regulation (EC) No 2016/183-of 11 February 2016 amending Implementing Regulation (EU) No 686/2012 allocating to Member States, for the purposes of the renewal procedure, the evaluation of the active substances whose approval expires by 31 December 2018 at the latest, Brussels

42. European Union (1991) Official journal of the European Union. Council directive 91/271/EEC of 21 May 1991 concerning urban waste-water treatment, Brussels

43. European Union (1998) Official journal of the European Union. Council directive 98/83/EC of 3 November 1998 on the quality of water intended for human consumption, Brussels

44. European Union (2000) Official journal of the European Union. Directive 2000/60/EC of the European Parliament and of the Council of 23 October 2000 establishing a framework for Community action in the field of water policy, Luxembourg

45. European Union (2005) Official journal of the European Union Directive 2008/50/EC of the European Parliament and of the Council of 21 May 2008 on ambient air quality and cleaner air for Europe, Strasbourg

46. European Union (2006) Official journal of the European Union Directive 2006/118/EC of the European Parliament and of the Council of 12 December 2006 on the protection of groundwater against pollution and deterioration, Strasbourg

47. European Union (2008) Official journal of the European Union. Directive 2008/105/EC of the European Parliament and of the Council of 16 December 2008 on environmental quality standards in the field of water policy, amending and subsequently repealing Council Directives 82/176/EEC, 83/513/EEC, 84/156/EEC, 84/491/EEC, 86/280/EEC and amending Directive 2000/60/EC of the European Parliament and of the Council, Strasbourg

48. European Union (2012) Official journal of the European Union. Regulation (EU) No 528/2012 of the European Parliament and of the Council of 22 May 2012 concerning the making available on the market and use of biocidal products, Strasbourg

49. European Union (2013) Official journal of the European Union. Decision No 1386/2013/EU of the European Parliament and of the Council of 20
November 2013 on a General Union Environment Action Programme to 2020 'Living well, within the limits of our planet', Strasbourg

50. United Sates Environmental Protection Agency (2018) Background on drinking water standards in the safe drinking water act. https:/www.epa. gov/dwstandardsregulations/background-drinking-water-standards-safedrinking-water-act-sdwa. Accessed 16 April 2018

51. United Sates Environmental Protection Agency (2018) Regional screening levels (RSLs)-Generic tables (november 2017). https:/www.epa.gov/ risk/regional-screening-levels-rsls-generic-tables-november-2017. Accessed 16 April 2018

52. United Sates Environmental Protection Agency (2018) Summary of the Clean Water Act. https://www.epa.gov/laws-regulations/summary-cleanwater-act. Accessed 16 April 2018

53. United Sates Environmental Protection Agency (2018) Summary of the Federal Food, Drug, and Cosmetic Act. https://www.epa.gov/lawsregulations/summary-federal-food-drug-and-cosmetic-act. Accessed 16 April 2018

54. United Sates Environmental Protection Agency (2018) Summary of the federal insecticide, fungicide, and rodenticide act. https:/www.epa.gov/ laws-regulations/summary-federal-insecticide-fungicide-and-rodenticideact. Accessed 16 April 2018

55. United Sates Environmental Protection Agency (2018) Superfund: CERCLA Overview. https://www.epa.gov/superfund/superfund-cerclaoverview. Accessed 16 April 2018

56. United Sates Environmental Protection Agency (2014) Priority pollutant list, Washington, D.C.

57. United Sates Environmental Protection Agency (2018) National primary drinking water regulations. https://www.epa.gov/ground-water-and-drinkingwater/national-primary-drinking-water-regulations. Accessed 16 April 2018

58. United Sates Environmental Protection Agency (2018) National recommended water quality criteria-Aquatic life criteria table. https:// www.epa.gov/wqc/national-recommended-water-quality-criteria-aquaticlife-criteria-table. Accessed 16 April 2018

59. United Sates Environmental Protection Agency (2018) National recommended water quality criteria-Human health criteria table. https:// www.epa.gov/wqc/national-recommended-water-quality-criteria-humanhealth-criteria-table. Accessed 16 April 2018

60. United States Food and Drug Administration (2018) Federal food, drug, and cosmetic act. https://www.fda.gov/RegulatoryInformation/Laws EnforcedbyFDA/FederalFoodDrugandCosmeticActFDCAct/default.htm. Accessed 16 April 2018

61. United Sates Department of Agriculture (2016) Pesticide data program, Washington, D.C.

62. United Sates Environmental Protection Agency (2018) About Codex. https://www.epa.gov/pesticide-registration/about-codex. Accessed 16 April 2018

63. Lim SJ, Oh YT, Kim SY, Ro JH, Choi GH, Ryu SH, Kim SS, Park BJ (2017) Residues of organochlorine pesticides in agricultural waters and its risk assessment of aquatic creature. Korean J Pesti Sci 21: 191-197 